\title{
Outcomes of renal transplantation in children with cystinosis
}

\author{
Esra Baskin ${ }^{1}$, Kaan Gulleroglu ${ }^{1}$, Aysun C Yilmaz ${ }^{1}$, Aydincan Akdur² ${ }^{2}$, Gokhan Moray ${ }^{2}$, Mehmet Haberal ${ }^{2}$ \\ ${ }^{1}$ Department of Pediatric Nephrology, Baskent University Hospital, Ankara, Turkey \\ ${ }^{2}$ Department of General Surgery, Baskent University Hospital, Ankara, Turkey
}

Background: Cystinosis is a rare lysosomal storage disease due to mutations in the CTNS gene. Although systemic disease manifestations continue, renal disease recurrence is not expected after transplant. We evaluate outcomes of renal transplant in children with cystinosis.

Methods: We retrospectively evaluated the data files from 165 pediatric renal transplant patients. Patients with cystinosis and patients with other etiologies of chronic renal failure were divided into two groups. Demographics of the patients, graft functions, infections, acute rejection episodes, and graft loss were recorded.

Results: One hundred sixty-five children (92 males and 73 females) with kidney transplant were enrolled to the study, eight of them had cystinosis. Although patients with cystinosis were youngest at the time of diagnosis when compared other patients $(0.69 \pm 0.42$ years vs. $7.76 \pm 5.20$ years; $P=0.00)$, mean ages at the time of the transplantation were similar $(12.28 \pm 4.57$ years vs. $12.95 \pm 4.75$ years; $P=0.69)$. Mean follow-up time after transplantation was $6.36 \pm 4.45$ years. Acute rejection episode rate was two times higher in patients with other etiologies (12.55\% vs. $24.87 \%)$. Glomerular filtration rate values at 3 years $(73.90 \pm 43.62 \mathrm{~mL} /$ $\min$ vs. $76.61 \pm 30.08 \mathrm{~mL} / \mathrm{min} ; \mathrm{P}=0.84)$ and 5 years of follow-up $(62.37 \pm 41.42 \mathrm{~mL} / \mathrm{min}$ vs. $62.82 \pm 32.82 \mathrm{~mL} / \mathrm{min}, \mathrm{p}=0.98)$ of two groups was similar. Eight patients (4.84\%) were lost their graft during 5 years of follow-up. One of these patients was in cystinosis group.

Conclusions: Renal transplant has similar outcomes, with lowest acute rejection episode rate in children with cystinosis when compared with other patients with different etiology of chronic renal failure.

Corresponding author: Esra Baskin

E-mail: rectorate@baskent.edu.tr

(c) The Korean Society for Transplantation

This is an Open Access article distributed under the terms of the Creative Commons Attribution Non-Commercial License (http://creativecommons.org/licenses/by-nc/4.0/) which permits unrestricted non-commercial use, distribution, and reproduction in any medium, provided the original work is properly cited. 